\title{
CONSCIOUS SELF-REGULATION OF VOLUNTARY ACTIVITY: DIFFERENTIAL APPROACH
}

\author{
Varvara I. Morossanova \\ Psychological Institute, Russian Academy of Education \\ Moscow
}

\begin{abstract}
This research is devoted to the investigation of the role of conscious self-regulation in human development and activity. The concept of conscious self-regulation of a subject's voluntary activity and the history of its research conducted in Psychological Institute RAE are discussed. The results of the research dedicated to the typology of individual styles of self-regulation and their relationship with educational and professional activity effectiveness are presented. Personal dispositions have specific influence on the individual peculiarities of regulatory profile. It is concluded that the integrated system of individual self-regulation includes dynamic and content aspects of a personality, its conscious and subconscious structures for development and achievement of goals.
\end{abstract}

Keywords: conscious self-regulation, subject and personality, individual style, self-regulation profile, personality dispositions.

\section{Introduction}

The principle of activity is one of the fundamental ones in Russian psychology. This principle is based on the notion that individuals react to their environment selectively and in different degrees, and that they are able to create, preserve, and change the context of their living. Within their life-span individuals face situations that require them to select personal goals and strategies for their achievement. But in a situation of choice, alleviating uncertainty is possible only with the help of psychic self-regulation system, which means that the individual sets goals, explores conditions, chooses the means of goal attainment, controls and corrects results while carrying out his or her activity. In this sense the in-

This research was supported by a grant No. 09-06-00620-a from the Russian Foundation for Humanities (RGNF). 
dividual is considered to be a kind of self-organizing system of regulation processes, which has its projections at varying levels of individuality.

Presently the problem of psychic self-regulation attracts the attention of an increasing number of researchers and practical psychologists. Today it can be quite a difficult task to find a psychological conference or a congress where the works devoted to a problem of self-regulation are not presented. Thus, more that 50 presentations on self-regulation were included in the scientific program of the International psychological congress in Berlin (2008). This article presents the results of the investigation of the role of conscious self-regulation in personal development and activity completed at the Psychological Institute of RAE, Moscow. These studies aimed at developing a fundamental trend in Russian psychology - the psychology of self-regulation.

The subject-matter of psychology of self-regulation is integrative psychic processes, which enable self-organization of psychic activity of the individual as an active subject of his or her actions, behavior, life-being, as well as the integrity of human individuality. The problems of self-regulation include regulation of functional conditions, general regularities and individual differences in self-regulation of behavior and activity, decision making processes, cognitive, personality, and emotional-voluntary regulation, individual styles of self-regulation and performance of various kinds of voluntary activity, nature of self-regulation, and age aspects of its development. One of the main perspectives of the modern psychology of self-regulation is to develop an integrated approach to the study of human being based on a concept of psyche as a self-organized subsystem in an integral system of interaction between a person and environment.

The problem of conscious self-regulation takes the central place in the context of individual development and existence. Goal-oriented regulation of individual's activity is the main mechanism enabling productive relationships between the subject and objective and social reality. When speaking of a person who accepts the aims of his operative actions and achieves them by using available and acceptable methods, we can talk of a conscious self-regulation.

It is typical for classical psychology to study the structure of selfregulation on the basis of physiology and psychophysiology materials and as components of different kinds of practical and psychic activities. When turning to a non-classical paradigm, we come to realize that psychic self-regulation as compared to physiological levels of in- 
dividuality has its specific features, and principles of cybernetics and synergetics can be applied to the analysis o psyche only as a metaphor. Psychic self-regulation is explored not so much from the standpoint of general regularities of activity self-regulation as from the standpoint of its individual manifestations relative to the individual's personal peculiarities; the general concept of self-regulation ability and the idea of individual styles of self-regulation of voluntary activity are being developed. In the $21^{\text {st }}$ century, the post-non-classical paradigm has won the leading place in Russian psychology. Its main distinctive feature is the inclusion of multiple paradigms, creation of integrated concepts of psyche and an increased interest in the development of self-regulation and self-organization. The focus has shifted towards the investigation of conscious self-regulation in the establishment of human individuality.

\section{The concepts of conscious} self-regulation, subject and personality

One of the topical problems of today, the problem of psychic selfregulation, became the subject of research at the Psychological Institute of Russian Academy of Education (RAE) in the 1960s.

Interestingly, the study of self-regulation started in the laboratory of labor psychology (led by D.A. Oshanin), which means that this fundamental scientific problem has been developed primarily in terms of practical needs, in the field of labor psychology, engineering psychology, and sport psychology.

The laboratory of self-regulation psychology was established in 1970 by O.A. Konopkin, a member of the Russian Academy of Education, who built the foundations of psychology of self-regulation as a scientific field in our country based on the ideas of famous Russian psychologists P.K. Anokhin, N.A. Bernstein, D.A. Oshanin and V.D. Nebylitsyn. In the earliest studies, sensorimotor reaction was viewed as an activity including psychic self-regulation, whose structure and functions have become the main object of the studies.

O.A. Konopkin proposed a conceptual model representing the most general structural- functional aspects of conscious self-regulation (Konopkin, 1980). The main functional components of conscious selfregulation process were distinguished: 
- Goal of the activity (as it is understood and accepted by subject);

- Subjective model of activity conditions significant for the achievement of the goal;

- Program of the activity;

- System of criteria of success of goal achievement;

- Evaluation of information regarding the results of the activity.

Conceptual ideas of self-regulation model were initially elaborated and experimentally tested in the field of human sensorimotor activity, later they were successfully applied to the analysis of regulation within the domains of educational, professional, and sport activity. The main mechanisms of self-regulation were revealed and it was proved that success in various kinds of activity is enabled by the formed integrated selfregulation system, where each poorly developed structural-functional element can seriously limit the effectiveness of actions in all kinds of activity. In other words, no matter how cognitively talented and competent an individual is, the high effectiveness of his activity is always guided by the mature and complete system of conscious self-regulation of the achievement of external practical and internal (directed towards oneself, towards resolution of personal developmental problems) goals. The dependence of productive aspects of activity on the development and completeness of conscious self-regulation system was found practically in all of our studies regardless of the forms of activity under investigation.

At the next stage, beginning with the early 90 s, the problem of conscious self-regulation was posed and solved in terms of voluntary human activity. The earlier model of self-regulation was adjusted and successfully applied to the analysis of human voluntary activity, the ideas about general ability for self-regulation were developed, operational and functional aspects of conscious self-regulation were singled out and their specific features and interrelations were described (Konopkin, 1995; Morossanova, 1995; Konopkin \& Morossanova, 1989).

Presently voluntary conscious self-regulation can be understood as a multilevel system process of psychic activity that influences the management of goal setting and goal attainment. At the same time the term awareness does not mean permanent actual representation of any activity in the individual's consciousness. It only means that the individual could on principle become aware of psychic self-regulation, as in the case of some difficulties or conscious construction of new plans and behavioral programs. And this conscious aspect of self-regulation, con- 
nected to specific features of human psyche, differentiates human selfregulation from self-regulation in animal world.

Our research on individual peculiarities of self-regulation represents substantial contribution to the development of the concept of conscious self-regulation. We have defined, described, and systematically analyzed the phenomenon of individual differences in self-regulation, which manifests itself in the way that people differ in the developmental level of conscious self-regulation, plan their activity goals and model the conditions of their achievement differently, apply different methods and algorithms to complete their actions, have different success criteria to evaluate the results (Morossanova, 1998).

Even at the first stages of our study we have discovered that the style of self-regulation is related to human individuality. The analysis of this complicated problem required not only extensive empirical investigations, but also a large amount of theoretical work. Theoretical research was devoted primarily to the relation between the concepts of personality, individuality, and subject. This research was conducted at the time when the concept of subject was just beginning to win its positions in the theory and methodology of Russian psychology. We were seeking for the substance of the philosophical concept of the subject within psychological reality, and the criteria for separating not only personality, but also these subjective aspects from multilevel structure of individuality.

From our point of view, individuality is the widest concept, which includes the subject and personality at all stages of individual development. When focusing on individuality as a subject of various kinds of activity, we investigate psychic self-regulation, which is a functional means of the subject and a psychological mechanism enabling him or her to mobilize his or her personality and cognitive recourses to complete his or her activity, to set and achieve its goals. The concept of subject emphasizes the active creative nature of the human, his ability to set and achieve subjectively accepted goals (Morossanova, 2006a; 2006c).

There are various forms and levels of subjectness. The operational level can be described by regulation profile of the development of self-regulation processes including goal planning, modeling of significant conditions, programming, correction of activity and its results. Another level is subjective or regulatory-personality traits such as responsibility, persistence, flexibility, reliability, and others. The intensity of these traits depends on the individual level of conscious self-regulation and specificity of the means 
by which the goals are achieved. In contrast to the subject's characteristics, personality structures determine not the way the goals are set and achieved, but what types of goals are set, what motivates the person and what his / her attitude to the world around him / her is. It is these subject's traits that determine the ability of the person to overcome subjective and objective difficulties in achieving his or her life goals and, along with the individual regulation profile, form the basis for the development of individual self-regulation profiles across various forms of the subject's activity.

Thus, from our point of view, the concepts of subject and personality describe different aspects of human individuality, which interact and organize the inner world and its manifestations in the person's behavior. Subjectness is represented primarily in self-determination, in the development of conscious self-regulation of activity. Meanwhile, personality determines individual peculiarities of self-regulation in their connection to temperament, character and various structures of self-consciousness and the unconscious.

\section{Individual style of self-regulation} and productiveness of person's activity

Over the past years, we have been studying individual differences in self-regulation across various types of activity - operator's, athlete's and scholar's. We have found evidence suggesting the existence of persistent individual differences in the way a person plans, programs, and estimates the results of his / her activity. Essentially, it implies individual styles of self-regulation. Self-regulation styles are individual features of organization and management of external and internal activity that are typical and most important to a person. These features constantly manifest themselves in various kinds of activities. Firstly, stylistic features of self-regulation are determined as individual differences in processes implementing the main components of self-regulation system. Secondly, stylistic features that characterize the function of all components of self-regulation system are at the same time personal traits (e.g. independence, flexibility, and reliability). The structure of individual differences is characterized by different stages of development of stylistic features or different individual profiles of regulation. Thus, we study first the operational aspects of the activity excluding its contents. This allows us to exercise a uniform approach, comparing individual peculiarities of 
the main regulatory processes across various types of activity, and identifying stylistic peculiarities of self-regulation.

The research of individual self-regulation peculiarities led to the development of special diagnostic and evaluation methods. In order to study and diagnose the described features the following questionnaire methods have been developed and standardized: Style Features of Behavioral Self-Regulation (SSB), Sportsman's Self-Regulation in Preparing to a Contest (SPS), Self-Regulation in Election Campaign of a Deputy (SIK), Individual Self-Regulation of Students (ISSH) (Morossanova, 1998).

The statements of the questionnaires were grouped into a number of scales, which assess typical individual peculiarities of regulatory processes pertaining to the task planning, situation modeling, actions programming, and results estimating. The results of testing make it possible to assess the individual level of self-regulation, which indicates ability to achieve the set goal, as well as to construct individual profiles of selfregulation reflecting the level of development of stylistic features of the main regulatory processes and personal regulatory traits.

The results of the investigation of individual self-regulation were published in Russian scientific journals Voprosy psihologii and Psihologičeskij žurnal and were summarized in the monograph Individual'nyj stil' samoregulâcii [Individual style of self-regulation] (Morossanova, 1998). We described the style of self-regulation with structural and level characteristics of regulatory system. The level characteristics reflect the degree of development of individual components and the system as a whole. The structural characteristics reflect specific features of a regulatory profile of self-regulation. According to these characteristics, harmonious and accentuated self-regulation styles can be distinguished.

Subjects with the harmonious style of self-regulation have all nodes of regulation developed to approximately the same extent. Such styles of self-regulation are formed when professional activity sets higher demands on the development of self-regulation. For example, we have diagnosed harmonious styles of self-regulation among sportsmen of highest professional category. This study included 119 high-class shooters aged 21 to 29. The study was undertaken during four sport seasons in the period of preparation and selection for the national Olympic team. The main criterion for selection to the national team was high stability and reliability of competition results. Such a sampling provided unique opportunities of identifying and describing the phenomenon of self-regulation style, 
elaborating its role in mediating the impact of personality structure, success, and the reliability of activity. Indeed, athletes who are national team candidates are professionals of equally high class, i.e., relatively equal in their professional skills. They are all highly motivated to reach one and the same goal - participation and victory at the Olympic Games and this goal subordinates their way of life. At the final stages of selection, most of the training takes place at one training base where the athletes are placed in the same conditions. Therefore the internal psychological factors become of special importance to successful training with, as we assume, more important roles to be played (1) by individual degree of development of the training goal-planning processes at various stages of training, (2) by programming means and objectives of general and special training, (3) by the ability to consciously subordinate to adopted plans and adjust them depending on the competition, and (4) by showing the successful results at various stages of training as well as maintaining the reliable sensorimotor regulation during play-off competitions.

A proprietary questionnaire technique was used - Sportsman's SelfRegulation in Preparing to Contest (SPS) (Morossanova, 1998). The questionnaire was based on the principle of identifying the athlete's attitude towards various methods of educational, training, and competitive activity organization and self-organization.

A regulatory profile was obtained for every athlete that comprised five individual assessments for each scale and the grand total, which characterized the individual level of conscious self-regulation of athletic activity. It appears that the high level of self-regulation makes a significant contribution to reliability of individual athletic activity.

In evaluating the individual success on the basis of play-offs results, two groups of athletes were singled out with different athletic training efficiency: the first group was composed of athletes who passed the whole multi-level system of selection and were included in the national Olympic team ("successful" group); the second group was composed of the athletes who failed to overcome the play-offs barrier and were not included in the national Olympic team ("unsuccessful" group). A comparison of these two groups revealed that the general degree of conscious self-regulation system development as well as the scores on all scales except the flexibility scale were significantly higher in the "successful" group compared to the "unsuccessful" group.

Of all sportsmen selected two contrast groups were identified in the quartile scale on the basis of general self-regulation level. In comparing 
athletic success in these contrast groups, the point biserial correlation factor turned out to be equal to 0.51 , which is meaningful at $p<0.01$. Among the athletes who passed the selection to the national team based on the results of three rounds of play-offs $80 \%$ were from the group of high regulation rating, and none from the low rating group. In our opinion these facts suggest that a high level of individual self-regulation is a pre-requisite for a high reliability of the activity performed.

Later it was proved that harmonious styles of self-regulation are typical for individuals with well-developed subject's traits like responsibility, self-confidence and persistence (Morossanova \& Plahotnikova, 2004b).

Of course these results do not mean that effective activity could be achieved only by individuals with harmonious styles of self-regulation. If the self-regulation profile is accentuated, the formation of effective or ineffective self-regulation style depends not only on the level of self-regulation development, but also on the correspondence of specific regulatory characteristics of activity to individual regulation profile structure, and the emergence in the process of style formation of compensatory relations between strong and weak aspects of self-regulation.

Thus, three styles with accentuated structure were distinguished - autonomic, stable and operative ones (Morossanova \& Sagiev, 1997; see Table 1).

Table 1

The structure of effective autonomic, operative and stable styles of self-regulation in educational activity of high school students

\begin{tabular}{|c|c|c|c|}
\hline \multirow[b]{2}{*}{ Style / Type } & \multicolumn{3}{|c|}{$\begin{array}{l}\text { Structure of individual style characteristics } \\
\text { of regulation processes }\end{array}$} \\
\hline & Strong traits & Weak traits & $\begin{array}{l}\text { Compensation } \\
\text { vector }\end{array}$ \\
\hline $\begin{array}{l}\text { Autonomic: } \\
\text { a) in goal planning }\end{array}$ & Planning (Pl) & $\begin{array}{l}\text { Modeling }(\mathrm{M}) \\
\text { Result evaluation }(\mathrm{Re})\end{array}$ & $\begin{array}{l}\mathrm{Pl} \rightarrow \mathrm{M} \\
\mathrm{Pl} \rightarrow \mathrm{Re}\end{array}$ \\
\hline b) in controlling & Result evaluation (Re) & Planning (Pl) & $\mathrm{Pl} \leftarrow \mathrm{Re}$ \\
\hline $\begin{array}{l}\text { Operative : } \\
\text { a) in conditions } \\
\text { evaluation }\end{array}$ & Modeling (M) & $\begin{array}{l}\text { Planning }(\mathrm{Pl}) \\
\text { Programming }(\mathrm{Pr})\end{array}$ & $\begin{array}{l}\mathrm{Pl} \leftarrow \mathrm{M} \\
\mathrm{M} \rightarrow \mathrm{Pr}\end{array}$ \\
\hline $\begin{array}{l}\text { b) in action } \\
\text { programming }\end{array}$ & Programming $(\mathrm{Pr})$ & $\begin{array}{l}\text { Planning }(\mathrm{Pl}) \\
\text { Modeling }(\mathrm{M})\end{array}$ & $\begin{array}{l}\mathrm{Pl} \leftarrow \operatorname{Pr} \\
\mathrm{M} \leftarrow \mathrm{Pr}\end{array}$ \\
\hline $\begin{array}{l}\text { Stable: in result } \\
\text { evaluation }\end{array}$ & $\begin{array}{l}\text { Planning } \\
\text { Result evaluation }\end{array}$ & Programming & $\operatorname{Pr} \leftarrow \operatorname{Re}$ \\
\hline
\end{tabular}


In accentuated as well as in harmonious styles specificity of individual profiles is mainly determined by the level of development of the subject's traits. Thus, flexibility is characteristic of operative style of selfregulation, independence is characteristic of autonomic style, and reliability is characteristic of stable style.

It should be emphasized that none of the defined styles can be considered preferable in terms of success in educational activity. Academic progress in groups characterized by different styles of self regulation did not differ statistically.

\section{Stylistic peculiarities of individual self-regulation and personality dispositions}

For the last 15 years we have consistently advanced the thesis that personality structures of different levels have an influence on what goals a person sets and how he / she sets them; they also modulate in a specific way the individual profile of self-regulation.

In fact we are speaking of creating a new field of the psychology of individual differences - that of individual differences in self-regulation of voluntary activity. Traditionally stable differences in human behavior are described by psychologists through the concept of traits and types of temperament and intelligence, and of personality. The nature of these differences is viewed usually through the prism of genetic and environmental factors, and is associated with human constitution, physiology and psychophysiology. The investigation of individual differences in conscious self-regulation allows us to take a new look on many problems within psychology of individual differences. Firstly, there is the influence of subject's activity on manifestations of individual temperament and character. The methodology and methods that we have developed make it possible to substantiate the following statement, both from the theoretical and empirical points of view. The temperament and character certainly set some biologically determined individual characteristics of behavior as well as of its self-regulation. At the same time subject's own activity, whose main mechanism is conscious self-regulation, influences temperament and character manifestations, can widen the norm of reaction, and allows the person to introduce considerable changes into the productive aspects of his / her activity.

To support this statement we investigated the regulatory basis of personality accentuations of character (according to K. Leonhard's clas- 
sification, 1976). For each typological group we succeeded in identifying specific profiles of self-regulation and describing the corresponding effective styles of self-regulation in education activity in psychological characteristics of students (Morossanova \& Sagiev, 1997).

Of all personality constructs under analysis, our project was focused on personal dispositions of extraversion and neuroticism (as assessed by $H$. Eysenck questionnaire) took a central place in our project; we sought to widen these concepts from the point of view of typical structures of individual characteristics of self-regulation.

In our latest studies (Morossanova, 2002; 2003), the regulatory basis of extraversion and neuroticism (Eysenck \& Eysenck, 1985) was identified. The research was conducted on high school students (856 Russian students aged 17-21). The methods used included Eysenck Personality Questionnaire (EPQ, Russian version, Rusalov, 1992) and Self-regulation Profile Questionnaire (SPQ, Morossanova \& Konoz, 2000). Seven typical self-regulation profiles of different structure in typological groups of extraverts, introverts, the emotionally-stable, and the emotionally unstable were identified. In fact, typical self-regulation profiles reflect the main tendencies in self-regulation of voluntary activity, which are characteristic for extraversion and neuroticism. This fact suggests the existence of common invariant regulatory basis for these temperamental dimensions of personality. These data were described in detail (Morossanova \& Konoz, 2000; Morossanova, 2003); here we present the structure of the main profiles of self-regulation (Fig. 1).

In this study, we have also shown how the typical profiles can change at various levels of conscious self-regulation development. It was shown that for a highly developed self-regulation system, the profiles are characterized by highly developed and closely interconnected main components of self-regulation structure, i.e. harmonious self-regulation style, which allows one to compensate the influence of personality characteristics and traits hindering successful goal achievement.

In typical self-regulation profiles, among the weak links in self-regulation system there are those, which do not easily lend themselves to compensation through a highly developed general self-regulation level and which are the most stable stylistic self-regulation aspects, thus representing limitations for the effective self-regulation formation. For extraverts and stables this weak regulation aspect is planning. For introverts the weak link is modeling of significant conditions, for the emotionally 

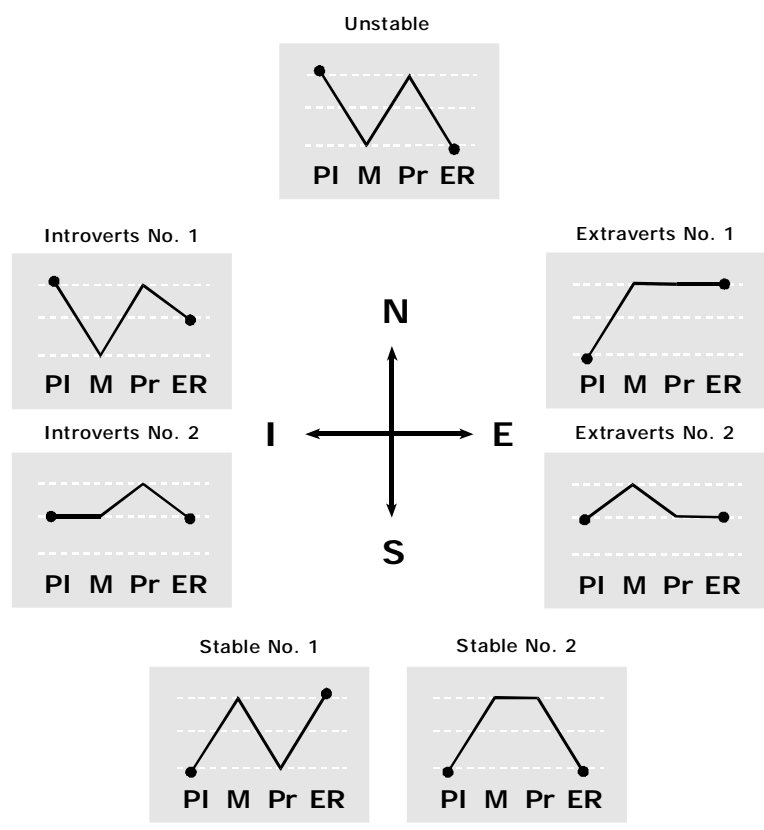

Figure 1. The typical self-regulation profiles of extraverts, introverts, neurotics and stables.

$\mathrm{Pl}$ - training planning, $\mathrm{M}$ - modeling of conditions, $\mathrm{Pr}$ - programming of actions, ER - result evaluation.

unstable the weak link is result evaluation. On the other hand, among the strong regulation traits are those that are resistant to the decrease in the level of conscious self-regulation. In individuals with a high level of neuroticism and in introverts, the regulation aspects of planning and programming can retain functional maturity even at a low level of conscious self-regulation, for extraverts and stables such trait is modeling.

Another study of ours (Morossanova, 2006c) was aimed at a comparison of Big 5 personality dispositions (De Raad, 2000) and the structure of individual self-regulation. The sample included 708 Russian students aged 16-17, who completed the FFI-NEO (Russian version), EPQ (Russian version) and SPQ (Self-regulation Profile Questionnaire). Typical self-regulation profiles of the subjects with extreme scores of extraversion and neuroticism were identified. It was shown that conscientious- 
ness (Big 5) correlated highly with the general level of conscious selfregulation (SPQ-98). These data suggest a conceptual and instrumental proximity of these concepts.

It has also been shown that higher levels of conscious processing in self-regulation modulate the effects of personality dispositions, balancing the extreme manifestations of underlying temperamental tendencies. Thus, when the level of conscious self-regulation increases, we can notice the reduction in the openness to new experiences typical for extraverts. Meanwhile when the level of conscious self-regulation increases in introverts, who are more closed to external stimulation, we can notice an increase in the characteristic of openness. This implies turning on the compensatory mechanisms of conscious self-regulation.

Then the question arises concerning the qualities of social-psychological level, more precisely, social motives and values: are their content and directionality connected with the level of development of conscious self-regulation of human behavior in society?

To find an answer to this question we compared individual differences in self-regulation of individuals with pro-social aggressive behavior and antisocial behavior (Garaleva \& Morossanova, 2006). The group of pro-social aggressive behavior included 223 men who had taken part in military operations. The group with antisocial behavior included 148 men convicted of violent crimes. We compared these groups in terms of personality and self-regulation characteristics.

The results suggested that the level of personal aggressiveness did not determine the direction of aggressive behavior (pro-social or antisocial). Personal aggression level (as assessed by Bass-Darky questionnaire) was high in both groups. At the same time, the groups differed in the level of development of conscious self-regulation. The level of conscious self-regulation was significantly higher in military men with pro-social aggressive behavior. Thus, with a higher level of conscious self-regulation the risk of anti-social aggressive behavior manifestations decreases. At the same time the development of conscious self-regulation provides only potential opportunities for effective control of aggressive behavior. If individual goals and motives are criminal, a high level of self-regulation system development can become a powerful tool for planning and organizing a crime. Pro-social aggressive behavior requires the conscious control of aggressive impulses. Probably for individuals characterized by the highly developed self-regulation system and high 
personal aggression, pro-social aggressive behavior is more typical; this behavior is displayed in professions, where aggression is an important professional quality.

We also studied the manifestations of individual self-regulation in decision making situations, in this case political voting situations (Morossanova \& Indina, 2007). In that study, personality and regulation determinants of rational decision making were discovered. The association between self-regulation and personality factors during rational decision making was investigated using an experimental model of political voting. The results revealed different sets of personality characteristics for rational and emotional voters. A self-regulating personality typology of decision making was then constructed, and traits representing self-regulation, cognition, and personality were examined as predispositions toward rational decision making. As a result, specific connections among these variables were revealed. Through these connections, the primary role of the conscious self-regulation system in the management of rational decision making in a political voting context was established.

In terms of self-regulation, rational decision making was defined as an adequate evaluation of alternatives involving personal goals, the search for needed information, the analysis of relevant external and internal conditions, the consideration of the methods and tools needed to implement the decision, and the evaluation of the consequences of the decision.

Various differences between the rational and emotional groups in terms of self-regulation, personality, and cognitive traits were revealed. Subjects in the high rationality group were characterized as significantly higher in general self-regulation, conscious goal planning, programming of actions, modeling of significant conditions, and estimating of consequences compared to subjects in the high emotionality group. In terms of personality, more rational subjects scored higher on thinking, judging, introversion, general rationality, and general intelligence. More emotional subjects scored lower than more rational subjects on general self-regulation, but higher on flexibility. More emotional subjects also scored higher on extraversion, impulsivity, general emotionality, and risk-readiness, but lower on general intelligence and general rationality.

The self-regulation typology is expressed differently in the high rationality and the high emotionality groups. For the high rationality group, four subtypes were distinguished: "rational programming," "rational plan- 
ning," "rational evaluation," and "rational modeling." For the high emotionality group, there were two types of regulation: "emotional-extraverted," and "emotional-neurotic." Each subtype is associated with a specific composite of self-regulatory, personality, and cognitive characteristics.

The study has proved the fact that general self-regulation plays an important role in decision making, particularly in the context of political voting. The self-regulation system mediates the influence of cognitive and personality characteristics on decision making, and increases the rationality of decision making processes (Morossanova \& Indina, 2007).

In yet another study, we have investigated personal preferences and orientations using Edwards Personal Preference Schedule (EPPS), and Personal Orientation Inventory (POI), both adapted to Russian population. Voluntary self-regulation was studied with Self-regulation Profile Questionnaire (SPQ, Morossanova, 2006b). We divided the sample into three groups of high, medium and low levels of total voluntary self-regulation. Comparative analysis of groups with high and low total levels of self-regulation has shown that there are some peculiarities in personal preferences and orientations within these groups. People with a high level of voluntary self-regulation are oriented primarily towards the present rather than the past and / or future. For the most part, they embrace the values of self-actualization, and aim at self-actualization and self-realization. People with low level of the voluntary self-regulation are characterized by abasement. Correlations between personal preferences, orientations, and voluntary self-regulation supported these results. The total level of voluntary self-regulation correlated with the endurance, time ratio, self-actualizing value, and self acceptance scales. The total level of self-regulation had an inverse correlation with abasement scale. Thus, voluntary self-regulation is interrelated with personal preferences and orientations (Morossanova \& Aronova, 2007).

The ideas about personality and regulatory individual and typical characteristics in high school students open up opportunities for drawing up developmental programs that would focus on self-regulation skills, self-consciousness, and current and future self-image modification (Morossanova \& Plahotnikova, 2004a).

To summarize the extensive research on personality characteristics of individual aspects of self-regulation the following should be noted. The subject's activity in setting and achieving goals is mediated by the integrated system of individual regulation, which functions as a tool for 
integrating and connecting the dynamic and content aspects of personality, its conscious and unconscious structures for goal setting and goal attainment.

\section{References}

De Raad, B. (2000). The Big Five Personality Factors: The Psycholexical Approach to Personality. Seattle: Hogrefe \& Huber.

Eysenck, H.J., \& Eysenck, M.W. (1985). Personality and Individual Differences: A Natural Science Approach. New York: Plenum.

Garaleva, M.D., \& Morossanova, V.I. (2006). Stilevye osobennosti osoznannoj samoregulâcii agressivnogo povedeniâ [Stylistic Differences of Self-Regulation of Aggressive Behavior]. In V.I. Morossanova (Ed.), Ličnostnye i kognitivnye aspekty samoregulâcii deâtel'nosti čeloveka [Personality and Cognitive Aspects of Self-Regulation of Human Activity] (pp. 99-113). Moscow: PI RAO.

Konopkin, O.A. (1980). Psihologičeskie mehanizmy regulâcii deâtel'nosti [The Psychological Mechanisms of Activity Regulation]. Moscow: Pedagogika.

Konopkin, O.A. (1995). Psihičeskaâ samoregulâciâ proizvol'noj aktivnosti čeloveka: strukturno-funkcional'nyj aspekt [Psychic Self-Regulation of Voluntary Activity: Structure-Functional Aspect]. Voprosy psihologii, 1, 5-12.

Konopkin, O.A., \& Morossanova, V.I. (1989). Stilevye osobennosti samoregulâcii deâtel'nosti [Style Peculiarities of Activity Self-Regulation]. Voprosy psihologii, 5, 18-26.

Leonhard, K. (1976). Akzentuierte Persönlichkeiten. Berlin: Springer.

Morossanova, V.I. (1991). Stilevye osobennosti samoregulâcii ličnosti [Style Peculiarities of Personality Self-Regulation]. Voprosy psihologii, 1, 121-127.

Morossanova, V.I. (1995). Individual'nyj stil' samoregulâcii v proizvol’noj aktivnosti čeloveka [Individual Style of Self-Regulation in Humans' Voluntary Activity]. Psihologičeskij žurnal, 4, 26-35.

Morossanova, V.I. (1998). Individual'nyj stil' samoregulâcii: fenomen, struktura $i$ funkcii v proizvol'noj aktivnosti čeloveka [The Individual Style of Self-Regulation: The Phenomenon, Structure and Function in Human Voluntary Activity]. Moscow: Nauka.

Morossanova, V.I. (2002). Ličnostnye aspekty samoregulâcii proizvol'noj aktivnosti čeloveka [Personal Aspects of Self-Regulation of Human Voluntary Activity]. Psihologičeskij žurnal, 6, 5-17.

Morossanova, V.I. (2003). Extraversion and Neuroticism: The Typical Profiles of Self-Regulation. European Psychologist, 4, 279-288.

Morossanova, V.I. (2006a). Sub"ekt i ličnost'v issledovaniâh osoznannoj samoregulâcii proizvol'noj aktivnosti čeloveka (Vmesto vvedeniâ) [Subject and Personality in Researches of Consiousness Self-Regulation of Voluntary Human Activity (In place 
of Introduction)]. In V.I. Morossanova (Ed.), Ličnostnye i kognitivnye aspekty samoregulâcii deâtel'nosti čeloveka [Personality and Cognitive Aspects of Self-Regulation of Human Activity] (pp. 7-16). Moscow: PI RAO.

Morossanova, V.I. (2006b). Stil' samoregulâcii povedeniâ (SSPM). Rukovodstvo po ispol'zovaniû [Style of Self-Regulation of Behavior. Methodological Handbook]. Moscow: Kogito-Centr.

Morossanova, V.I. (2006c). Stilevye osobennosti individual'noj samoregulâcii i ličnostnye dispozicii čeloveka [Stylistic Differences in Individual Self-Regulation and Personality Dispositions]. In V.I. Morossanova (Ed.), Ličnostnye i kognitivnye aspekty samoregulâcii deâtel'nosti čeloveka [Personality and Cognitive Aspects of Self-Regulation of Human Activity] (pp. 18-39). Moscow: PI RAO.

Morossanova, V.I. (2007). Ot sub"ekta i ličnosti k individual'noj samoregulâcii povedeniâ [From Subject and Personality to Individual Self-Regulation of Behavior]. In V.I. Morossanova (Ed.), Sub"ekt i ličnost'v psihologii samoregulâcii [Subject and Personality in Psychology of Self-Regulation] (pp. 120-137). Stavropol: PI RAO, SKGTU.

Morossanova, V.I., \& Aronova, E.A. (2007). Samosoznanie i samoregulâciâ povedeniâ [Self-Consciousness and Self-Regulation of Behavior). Moscow: IP RAN.

Morossanova, V.I., \& Indina, T.A. (2006). Personality and Regulation Determinants of Rational Choice in Political Voting Situations. 13th European Conference on Personality (July 22-26, Athens, Greece): Conference Program and Abstracts Book (p. 277).

Morossanova, V.I., \& Indina, T.A. (2007). Psihologičeskie predposylki prinâtiâ racional'nyh rešenij na materiale golosovaniâ izbiratelej [Psychological Conditions of Rational Decision Making on Example of Electors' Voting]. Voprosy psihologii, 6, 74-85.

Morossanova, V.I., \& Konoz, E.M. (2000). Stilevaâ samoregulâciâ povedeniâ čeloveka [Style Self-Regulation of Human Behavior]. Voprosy psihologii, 2, 118-127.

Morossanova, V.I., \& Plahotnikova, I.V. (2004a). Razvitie osoznannoj samoregulâcii [Development of Conscious Self-Regulation]. Moscow: Verbum.

Morossanova, V.I., \& Plahotnikova, I.V. (2004b). Responsibility and Individual Differences in Self-Regulation. In B. De Raad, D. Barelds, K. Van Oudenhoven-Van der Zee (Eds.), 12th European Conference on Personality, July 18-22, 2004: Conference Abstracts (p. 189). Groningen, Germany.

Morossanova, V.I., \& Sagiev, R.R. (1997). Akcentuaciâ haraktera i stil' samoregulâcii u studentov [Character Accentuation and Self-Regulation Style in Students]. Voprosy psihologii, 6, 30-38.

Rusalov, V.M. (1992). Modificirovannyj ličnostnyj oprosnik Ajzenka [Modified Eysenck' Personality Questionnaire]. Moscow: Nauka. 